\title{
粗面開水路乱流の水面変動に及ぼす 乱流洞構造の条件付き抽出に関する研究 \\ EXTRACTION OF TURBULENCE EDDY STRUCTURE AFFECTING WATER SURFACE FLUCTUATION IN ROUGH WALL OPEN-CHANNEL TURBULENCE
}

\author{
小田崇裕 ${ }^{1} \cdot$ 藤田一郎 $^{2} \cdot$ 吉村英人 $^{3}$ ・岡西健史 ${ }^{4}$ \\ Takahiro ODA,Ichiro FUJITA, Hideo YOSHIMURA and Tateshi OKANISHI \\ 1 学生会員 神戸大学大学院工学研究科（†657-8501 神戸市灘区六甲台町 1-1） \\ 2 正会員 学博 神戸大学大学院教授 工学研究科（†657-8501 神戸市灘区六甲台町 1-1） \\ 3 タずほ情報総研株式会社 サイエンスソリューション部（†101-8443 東京都千代田区神田錦町 2-3） \\ 4 株式会社オージス総研 (†550-0023 大阪市西区千代崎 3 丁目南 2-37)
}

\begin{abstract}
In open-channel turbulence with relatively large Reynolds number, water surface is subject to various types of fluctuations depending on the strength of turbulence. The level of fluctuation varies also with the Froude number and several researches have been conducted with respect to the root-mean-square value of surface oscillation. However, the mechanism that creates such water surface features has not been executed in detail in terms of turbulence vortex structure especially in rough-wall turbulence. This research aims at extracting a vortex structure that directly affects the water surface phenomenon by using an experimental technique with PIV and a sophisticated numerical technique with LES. A three-dimensional vortex structure that has an impact on surface features was successfully extracted from the LES results by using a conditional sampling technique.
\end{abstract}

Key Words: rough-wall turbulence, water surface fluctuation, LES, vortex structure, PIV

\section{1.はじめに}

開水路の流れは自由水面を有しており，様々な影 響を受けて変動している．特に河床面が礫などで覆 われている粗面開水路においては，水面変動の様子 が河床面の粗度サイズや配置によって大きな影響を 受けるであろうことは容易に想像できるが，変動の 詳細や変動発生のメカニズムに関する研究例は非常 に少ない1). 水面はいわゆる気液界面であり, 界面 を通しての気体吸収のメカニズムが表面更新渦2)で 説明されるなど，環境を考えるうえでも重要な対象 であるにもかかわらず，実験的に詳細な検討が始ま ったのは最近になってからである3-5). これは, 近年 になって, 画像解析技術などのソフトウェア的な発 展と高速度カメラの高性能化によるハードウェアの 進展が同時に進んできたためであり，従来のサーボ 式波高計のように点計測しかできなかった時代から のレジーム変化があったことは確かである.

一方, 河川流を構成する河床面は砂礫で構成され るのが常であり，グローバルには粗度係数を通して 流水抵抗を及ぼす要素として古くから認識されてい る。したがって，いわゆる粗面開水路乱流に関する 研究は, 抵抗特性の解明という点では数多くの研究 が行われてきた ${ }^{6)}$. 境界層を対象とした粗面乱流に ついてはすぐれたモノグラフが出されている7-8). こ の分野においても水面変動との関連で水理現象が議 論されることはほとんどなかったが，これも最近に
なって高精度の計測に基づいた考察が行われるよう になってきた ${ }^{9-11)}$ 。例えば，Royら ${ }^{10)}$ は礫床河川にお いて多数並べた流速計を空間的に移動させて流速分 布の時空間構造を調べるとともに，その大規模構造 が流下方向に移流することやその構造が水深によっ て変化することなどを明らかにした．また，水面の 波形の移流については, Smolentsev and Miraghaie ${ }^{3)}$ が幅広い水理条件に対して検討を行っている。

実用的な側面から言えば，いわゆる非接触の河川 流速計測は水面で発生する波紋の移流速度が表面流 速を代表するとの仮説に基づいて計測が行われてお り，この仮説を支持する直接的な計測結果も示され ている12)が，実験室レベルの検討では波紋の移流速 度が表面流速よりも若干遅くなるという報告3)も出 されている。

以上のような先駆的研究に対して, 著者らは可視 化画像解析とLESによる解析により，栈粗度，半球 粗度，および任意形状でランダム配置の礫が河床を 構成する場合について検討を行っており ${ }^{12-17)}$, 水面 変動を含めた乱流場の理解を進めてきた。しかしな がら，特に砶を河床に配置した場合の検討について は，LESによる水面変動強度が実験值と比べてかな り小さく計算されるなど不備な点もあった。本研究 ではこれらの点を改善するとともに，水面に衝突す る渦構造を条件付きサンプリングにより抽出しその 特性を明らかにする。 

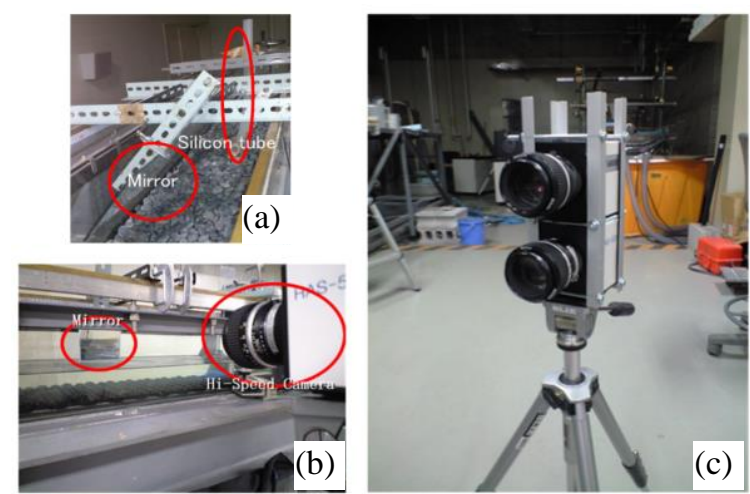

図-1 可視化実験装置のセットアップ: (a) シリコンチ ユーブとミラー配置，(b)ミラーと高速度カメラ

\section{2. 流れの可視化画像解析}

水面変動を有する開水路流れの詳細を時空間的 に把握するためには, 可視化画像解析の手法が有効 である。本研究では，岡西ら 17)によって開発され た水路縦断面における水面変動とその直下の流速 変動を同時に計測するシステムを利用した.このシ ステムでは，2 台の高速度カメラを用い，一つのレ 一ザー光膜で水面変動と流れ場を同時計測できる ように工夫している. 図-1 にその概要を示す.上 側の高速度カメラは, 水面よりも上にレンズ中心が 位置しており, レーザー光膜が水面と交差して生成 される曲線をキャプチャーする.特に工夫している のは, 光ファイバーをシリコンチューブに導き, 流 体内からレーザー光膜を照射している点である.シ リコンチューブの先端は, 図-2 に示すように円形 に整形したアクリル板をはめ込むという単純な工 夫で防水機能を実現している. 使用した水路は, 長 さ $600 \mathrm{~cm}$, 幅 $30 \mathrm{~cm}$ である. 水面変動のキャプチャ 一法や画像解析の詳細については前報 17)を参照さ れたい。

\section{LES による三次元流れ解析}

\section{（1）底面境界の再構成}

本研究では, 前報 17) と同様に Large Eddy Simulation (LES)による数值解析を並行して行って いる. 解析モデルの特徵は, 水面変動を密度関数に より計算し，河床の境界条件を IBM (Immersed Boundary Method)で与えている点である。したがっ て, 解析は気相においても行っている. 河床面は, ステレオ画像解析で計測した実際の粗面の DEM (Digital Elevation Model)データを繰り返し配置して 再現した. 前報では, 流れ方向 $40 \mathrm{~cm}$, 横断方向 $20 \mathrm{~cm}$ の 1 データをDEM データとして用いたが，個別の 礫の形状再現が不十分であったことや, 周期境界条 件を課した場合, 上下流断面間の距離が短いにもか かわらず両端での水位が自動的に等しくなるため, 水面変動強度が実験值と比較してかなり過小評価 されていた。

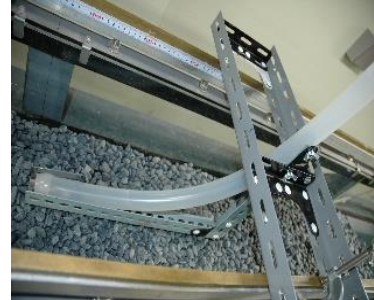

(a) シリコンチューブ

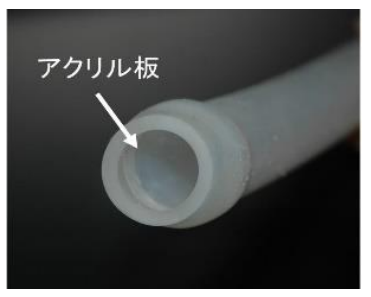

(b) 先端部
図-2 レーザー光膜の水中からの照射法

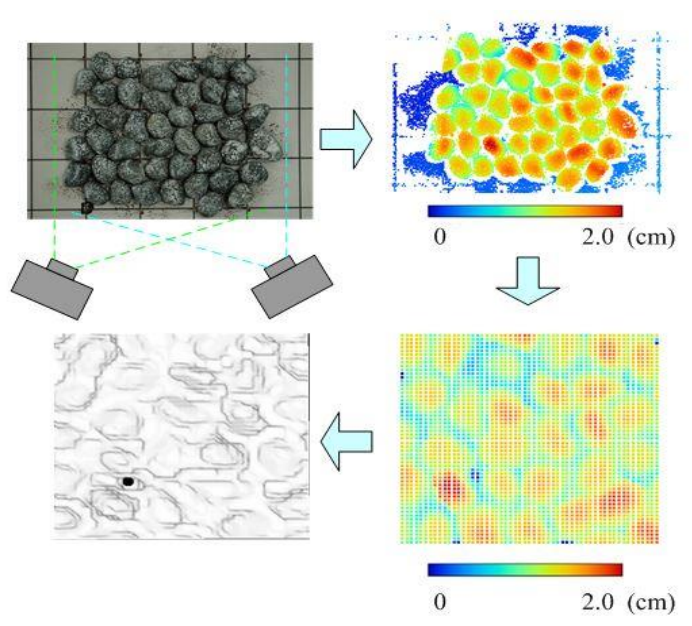

図-3 河床面データの取得法（左上：生画像, 右上 : ス テレオ画像解析後, 右下: 離散データ化, 左下: DEM データの俯瞰表現, 平均粒径 $1.5 \mathrm{~cm}$ )

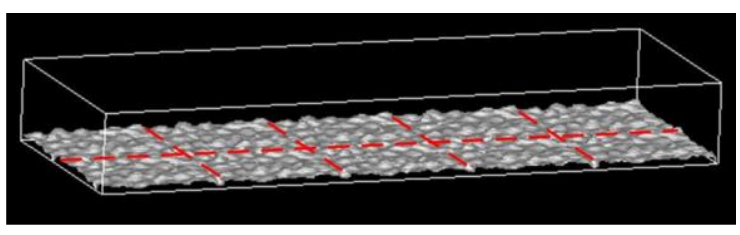

図-4 横 2, 縦 5 ユニットの底面境界 (主流方向 $68 \mathrm{~cm}$, 横断方向 $24 \mathrm{~cm}$ )

そこで, 本研究ではまず個別の礫に刷毛で斑点模 様を塗布して特徵を強調し, 礫床形状のさらに忠実 な再現を図った。DEM データ取得のプロセスを図 -3 に示す. ステレオ計測で得たデータは, LES 解 析の平面格子に合わせて離散化し，最終的な DEM データとした。ここで得られたのは，一辺が $12 \mathrm{~cm}$ 程度の長方形データなので, 数值解析ではこのデー タを一つのユニットと考え, データを縦横に繰り返 して並べることで広い底面境界を構成させた.ユニ ットの境界部分の高さデータはその周囲の高さデ 一タから補間することにより求めているのでユニ ット同士は滑らかに慗がれている. 本研究では，流 れ方向の周期境界の長さの影響を調べるために, 横 2 ユニット, 縦 5 ユニットのケースと, 横 2 ユニッ 卜, 縦 7 ユニットの2ケースについて解析を行った. なお，ユニットの配置に際しては，各ユニットを同 じ方向に単純に並べず，交互に向きを変えるなど， 粗面配置が周期的にならないように配慮した. 横 2 , 縦 5 ユニットの場合の底面境界を図-4 に示す. 平 
表-1 水面変動強度の比較

\begin{tabular}{c|c|c}
\hline & $\mathrm{Hrms} / \mathrm{H}$ & $\mathrm{L}(\mathrm{cm})$ \\
\hline \hline $\exp .(\mathrm{d}=1.0 \mathrm{~cm})$ & 0.0179 & - \\
\hline $\exp .(\mathrm{d}=1.5 \mathrm{~cm})$ & 0.0185 & - \\
LES. $(\mathrm{d} / 1.5 \mathrm{~cm})$ & 0.0030 & 40 \\
LES. $(\mathrm{d}=1.5 \mathrm{~cm})$ & 0.0053 & 68 \\
\hline LES. $(\mathrm{d}=1.5 \mathrm{~cm})$ & 0.0072 & 95 \\
\hline
\end{tabular}

面的なスケールは, 横 2 , 縦 5 ユニットが $24 \times 68 \mathrm{~cm}$, 横 2, 縦 7 ユニットが 24x95cm の細長い長方形であ る.

\section{(2) 解析条件}

解析は，実験に合わせて水深 $5 \mathrm{~cm}$, 礫の平均粒径 $1.5 \mathrm{~cm}$, フルード数 0.6 , レイノルズ数 21000 のケー スを対象とした. 粒子レイノルズ数は 742 で完全粗 面乱流の状態である. 水深は幾何学的基準面までの 深さとしている．解析メッシュは，鉛直方向 100 , 横断方向 80, 主流方向 200 (縦 5 ユニット) および 250 （縦 7 ユニット）である。解析空間は，液相の $5 \mathrm{~cm}$ の上層に厚さが $2.5 \mathrm{~cm}$ の気相の空間を設けて いる. 主流方向及び横断方向には周期境界条件を課 している.解析方法の詳細については前報 16-17)を参 照されたい。

\section{4. 本 LES モデルによる水面変動の再現性}

\section{（1）水面変動強度}

開水路の水面変動は, 実験においては流入部上流 水槽内の変動や水路側壁の継ぎ目の影響などのた めに本来の変動に加えてノイズが入り込んでいる と考えてよい.このような実際の実験状況を数值解 析で再現するのは難しいため, 周期境界による解析 は実験值よりは変動は過小評価されると思われる. ただし, 計算格子の解像度を高め, 周期境界を長く すれば変動強度は更に実験值に近づくと思われる. 表-1 に水面変動強度の比較を示したが，上記の考 察を裏付ける結果となっている. $L$ は周期境界の距 離である.ただし, 実験值はレーザー光膜を照射し た縦断線上の水面変動, LES ではすべての水面にお ける変動の double-average データを示している. 表 -1 より周期境界の流れ方向の距離の増大に伴って 変動強度が増していることがわかる。これは, 乱流 による影響だけではなく, 実際の実験でも見られる 長周期・長波長の変動が得られたためと思われる.

\section{（2）水面変動のスペクトル}

水面変動の LES モデルによる再現性を確認する ために, 任意点における水面変動のパワースペクト ルを図-5 に比較した。変動のエネルギーが異なる ために必ずしも一致はしていないが，実験と LES によるスペクトル形状には類似性が見られる.すな わち, 低周波側において同程度の卓越周波数が存在 すること, 高周波側のエネルギー低減の傾きがよく 似ていることなどである.また, 解析領域の長さを

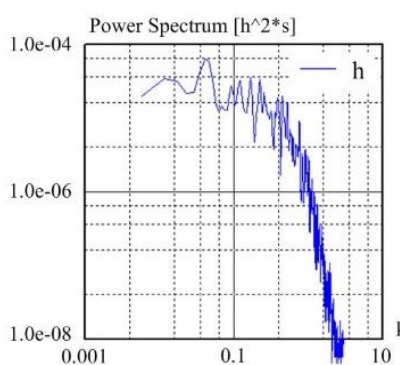

(a) $\exp .(\mathrm{d}=1.0 \mathrm{~cm})$

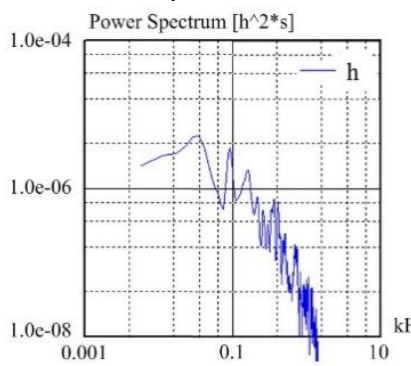

(c) LES ( $d=1.5 \mathrm{~cm}, \mathrm{~L}=68 \mathrm{~cm})$

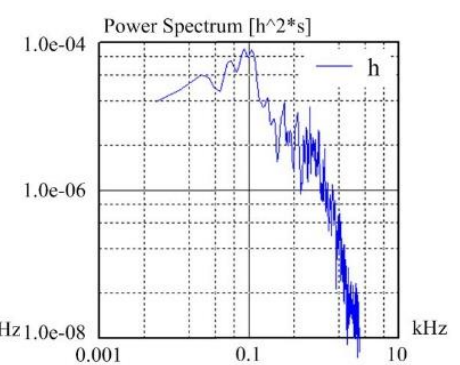

(b) $\exp .(\mathrm{d}=1.5 \mathrm{~cm})$

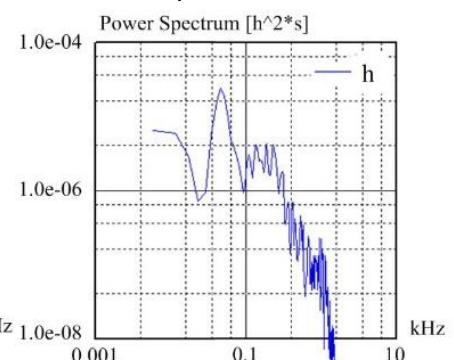

(d) LES (d=1.5cm, L=95cm)
図-5 水面変動スペクトル

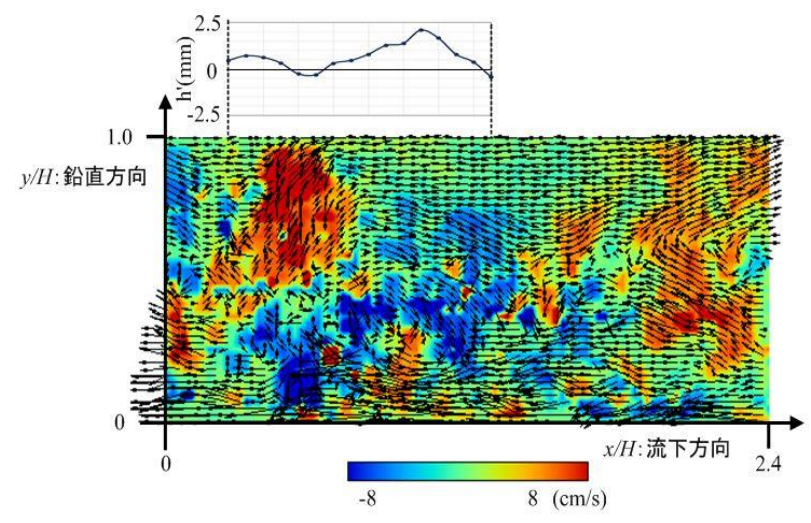

図-6 水面上昇時の内部流速場（実験: コンターは鉛直流速 成分, ベクトルは平均主流速を差し引いたものである. )

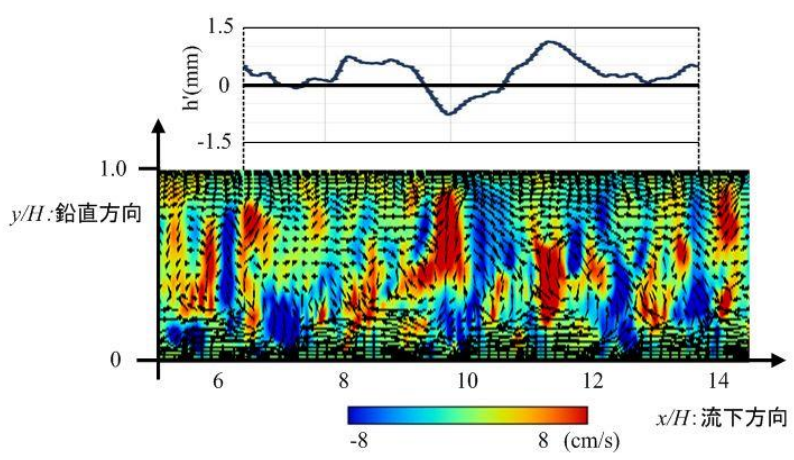

図-7 水面上昇時の内部流速場 (LES)

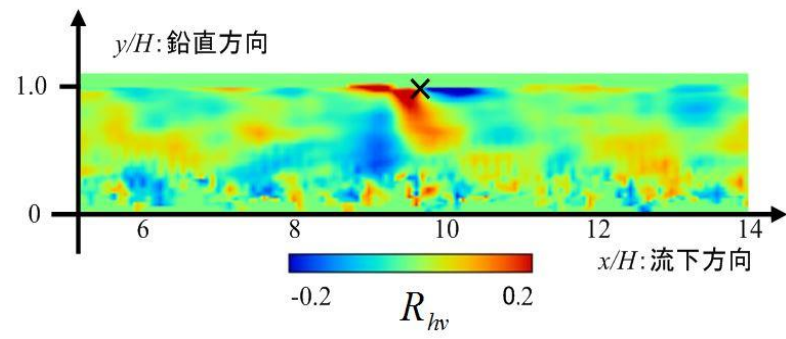

図-8 水面変動と鉛直速度の相互相関 
増加することによって, より明確なピークが現れて いる。 これらの点より，本 LES モデルでは実際の 水面変動を, 周波数のレベルでもある程度再現でき ていることが確認できた.

\section{5. 水面変動の発生要因に関する検討}

河川における水面変動の要因には，外因と内因が あることを岡西ら ${ }^{18)}$ は指摘しているが，ここでは純 粋に乱流渦の水面への接近や衝突によって発生する 水面変動を考える。

\section{（1）実験データに基づく検討}

本研究で用いている計測システムでは水面変動と 内部流速場の同時計測が可能であるため, 前報 ${ }^{17) て ゙ ~}$ は水面変動と鉛直流速成分の相互相関から，水面が 上昇するモードでは着目点の上流側で正の相関，下 流側に負の相関が分布すること, またそれらの相関 領域は水面付近に限定されることを示した. ここで は，局所的に水深が他の部分よりも盛り上がってい る場合の水面形とその瞬間の内部流速について調べ た．図-6にある瞬間の実験データを示す．水面形と 横軸のスケール及び位置はリンクしている. 水面の 盛り上がりは鋭い凸状ではなく緩やかな変化を示し ている. 同時にピーク水位の地点の上流側には上昇 から下降に転じる大きな渦構造が見られる。これら の流速分布パターンは短時間の間は凍結乱流的に下 流に移流する. と同時にピーク水位の地点の水面は 凸状から変化し, 次の変動モードに移行する. 寸な わち，水面を押し上げているのは確かに上昇流であ ることが推察される. 図-7 には, LES 解析で得られ た凸状の水面と内部流の結果を図-6に合わせて示 す. 実験結果と同様の傾向の構造を見て取れる.

可視化実験ではレーザー光膜内の二次元的な現象 しかとらえることができない，そこで，三次元的な 渦構造を含めた流れ場の詳細を調べるために，以下 では LES の解析結果に基づいた検討を進める.

\section{(2) 水面変動と鉛直速度の相互相関分布 (LES)}

図-8に示したのは，今回の $L E S$ データ $(L=95 \mathrm{~cm})$ に基づく×印で示す点における水面変動と鉛直流速 成分の相互相関分布である。相関係数の最大值は 0.33 であり, 禰津ら ${ }^{19)}$ の滑面における検討で得られ た值 0.04 と比較すると相対的に大きな值となってお り，粗面の影響が強く出ていることが確認できる. ここで重要な点は, 高い相互相関の領域が底面付近 にまでは達していない点である。このことは，水面 変動に影響を及ぼす乱流渦のうち, 底面から長寿命 を保ちながら水面に到達するものは少ないことを示 唆する. 大規模な砂漣などが発達している場合には, ボイル渦として底面から水面に到達するものがある が，極端な凹凸の少ない粗面乱流場では水面まで到 達するような渦度レベルの高い剥離渦は発生しにく い. このことは，水面に衝突して水面を変形させて いるのは，水面付近に集まった剥離渦の集合体では

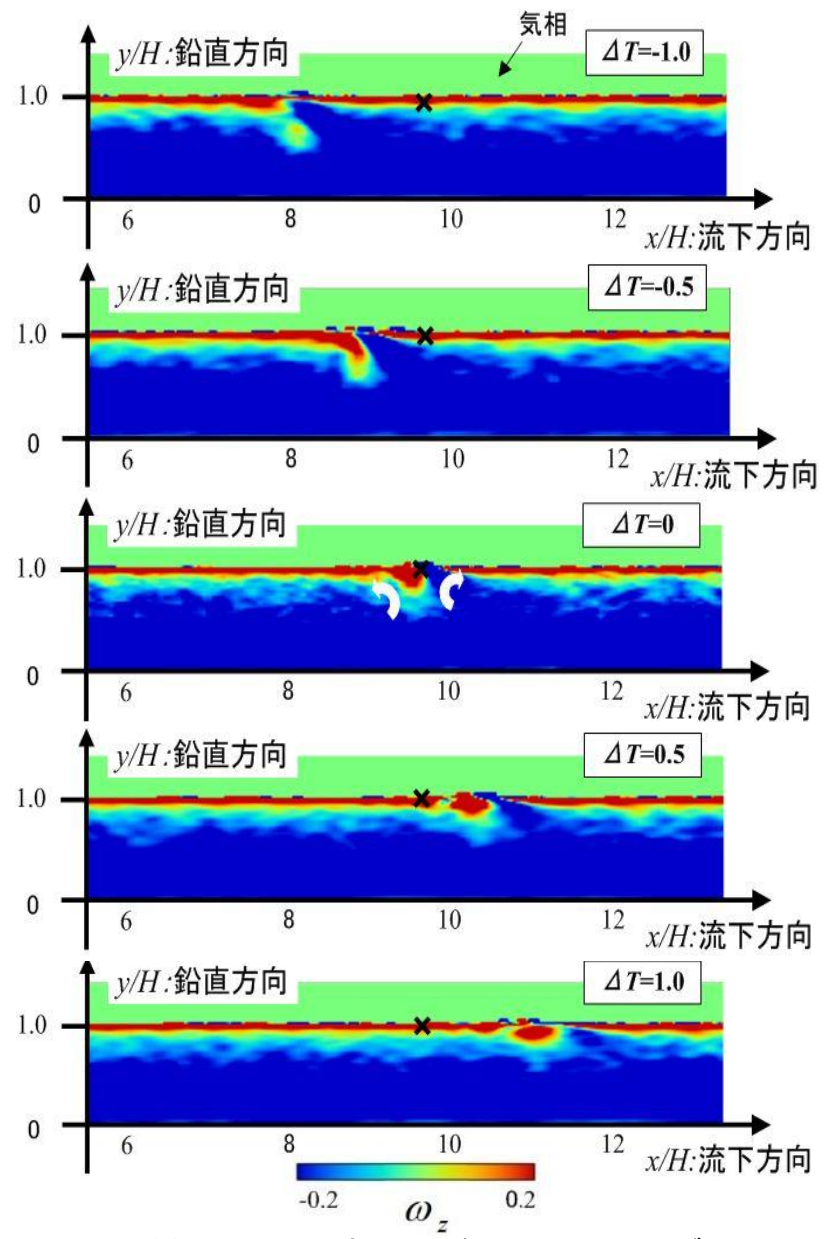

図-9 縦断面内の渦度 $\omega z$ の条件付アンサンブル 平均

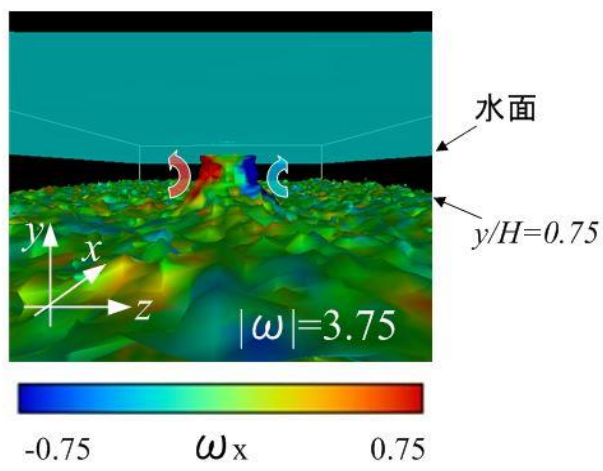

図-10 横断面内の渦度 $\omega_{\mathrm{x}}$ の条件付きアンサンブル 平均

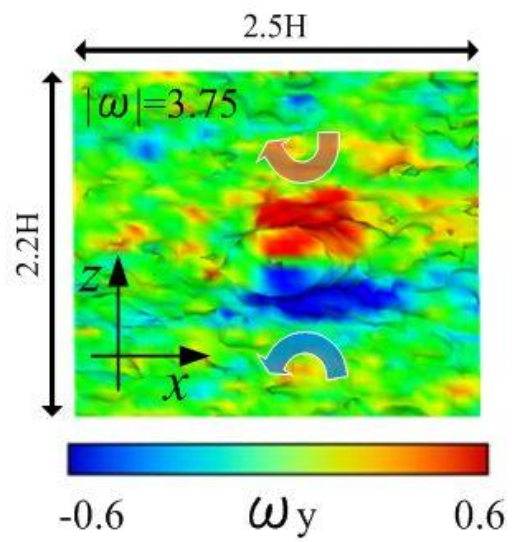

図-11 平面内の渦度 $\omega_{\mathrm{y}}$ の条件付きアンサンブル平均 

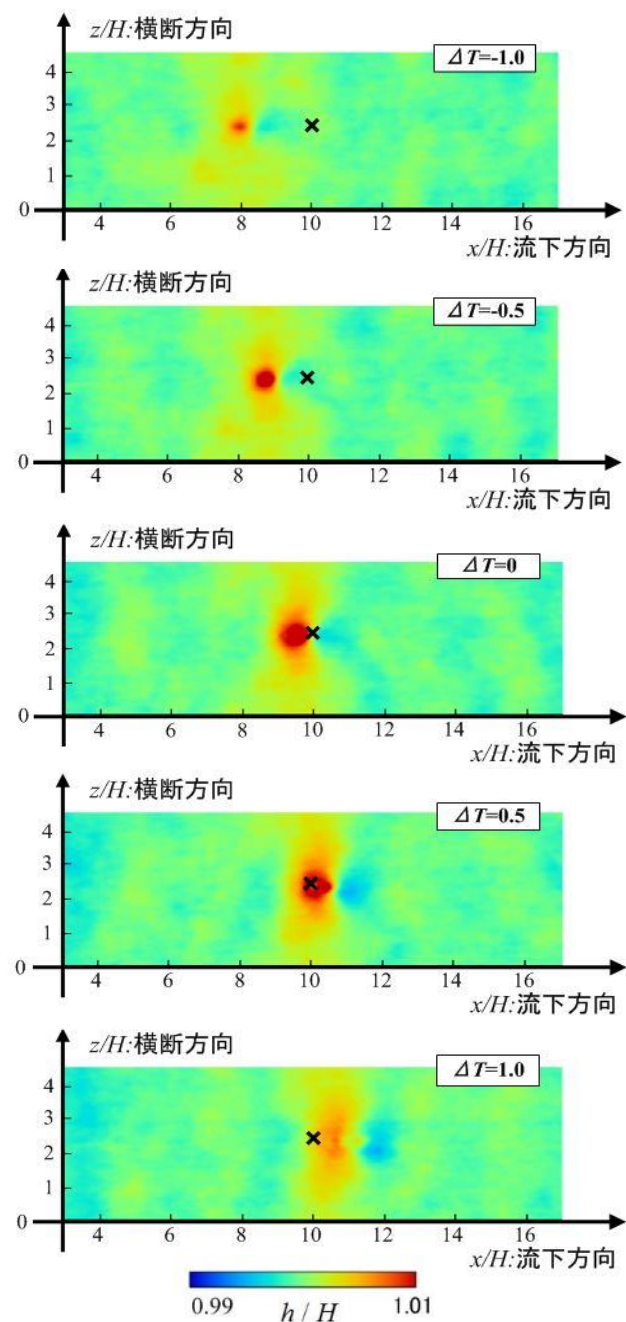

図-12 条件付きサンプリングされた水面衝突渦

ないかということを示唆している，実際に，実河川 では非常に水深の大きな流れにおいても水面は洪水 時には大きく変動しているわけであり, その変動の 駆動力となっているものがすべて河床から到達した 剥離渦と想定することは難しい。

\section{(3) 縱断面内の渦構造の抽出 (LES)}

水面に到達した瞬間の内部流れの渦構造を検出す るために，ここでは条件付きサンプリングを次の手 順で行った.

Step 1 : 時系列ごとに水面変動の最大点を検出する. 検出は水面を平面的にスキャンして行う.

Step 2 : 水面変動の最大点の直下におけるレイノル ズ応力を調べ，しきい值より大きな值をもつものだ けを選別する。（今回, しきい值は平均レイノルズ 応力の半値とした。)

Step 3 ：上の基準を満たした瞬間のベクトル場を空 間的にアンサンブル平均する.

Step 4 : Step 1 と Step 2 の処理をずれ時間 $\Delta T$ を与 えて行い, 時空間的な変化を調べる. $\left(\Delta T=\Delta t U_{m} / H\right.$, $U m:$ 平均主流速, $H:$ 平均水深, $t:$ 実時間)

このような条件付きサンプリングで求めた, 紙面 に垂直方向の軸をもつ渦度 $\omega_{z}$ の分布を図-9 に示す.
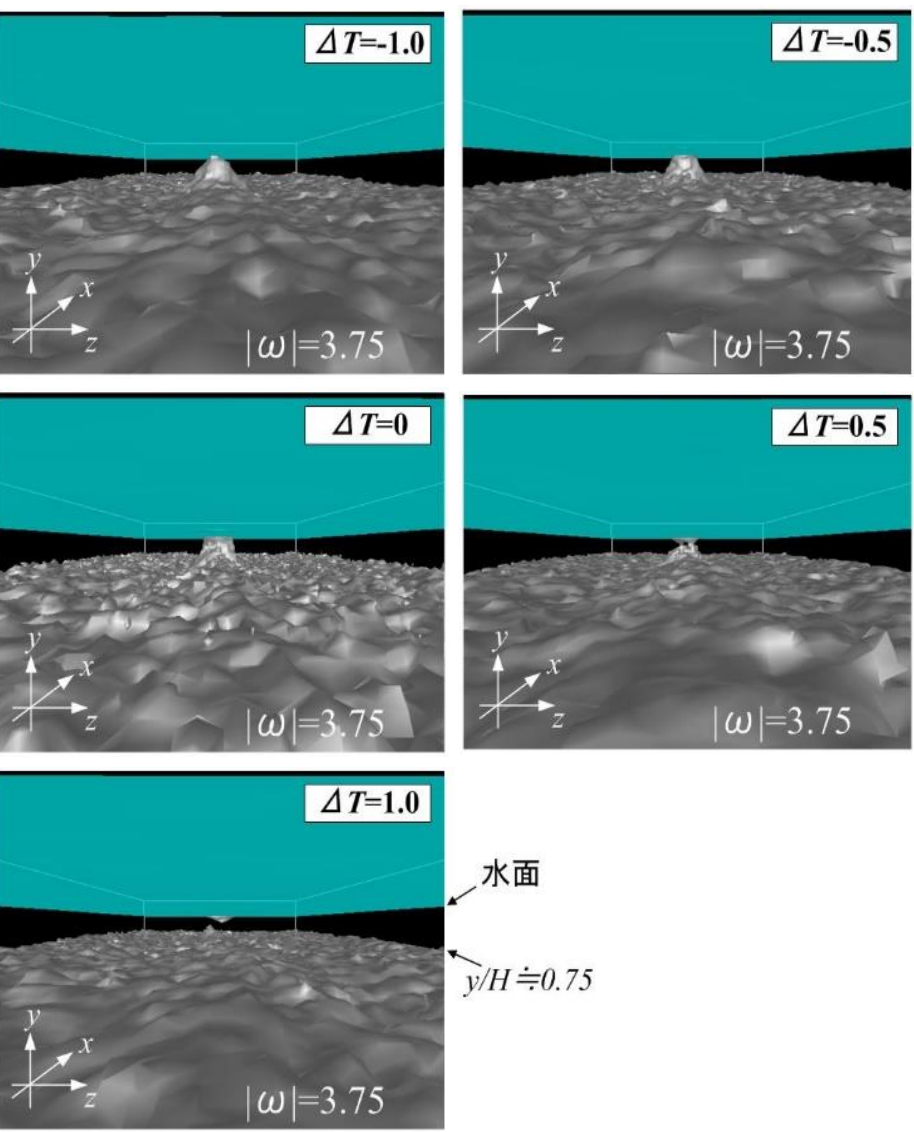

図-13 条件付きサンプリングされた水面衝突渦の三次元 構造 (渦度絶対值の等值面を白色, 水面位置を水色で示 す. )

×印で示した着目点の上流側では反時計回り，下流 側では時計回りの渦がうまく抽出されている。すな わち水面に衝突する渦はある構造を有していること がわかる，ズレ時間的にみると，水面に衝突する渦 は, 衝突の直前 $(\Delta T=-0.5)$ で強い強度を持つように なり，衝突後はその渦度をある程度保ちながら流下 している.この水面衝突渦を横断面の構造で見たも のが図-10である. 図中の $|\omega|$ は平均主流速と平均水 深で無次元化された渦度絶対值であり，その值の等 值面をプロットしている，渦度絶対值は最も構造が 分かり安いと思われる值とし，值を図上に示した。 渦の回転方向は縦断的に見た場合と同様に渦の中心 部が上昇するような方向となっていることがわかる。 図-11 には水平面内からみた水面衝突渦を示した. 周囲の流体を内側に巻き込むような回転構造が見て 取れる. 図-9 から図-11より推定される渦構造は内 側が上向きに斜めに回転するドーナツ状の形状であ ることが推定される.

水面衝突渦による水面の変形をずれ時間を与えて 調べたのが図-12 である. 水面衝突渦は×印で示し た着目点に接近する前から水面を多少盛り上げてお り，衝突時には局所的に約 3.5\%の水面上昇があった。 衝突後は中心にわずかな凹みが現れるが，流下とと もに短時間で拡散する。

図-13 は水面衝突渦の渦度の絶対值 $|\omega|=3.75$ の等 值面を三次元的にプロットしたものである。この值 


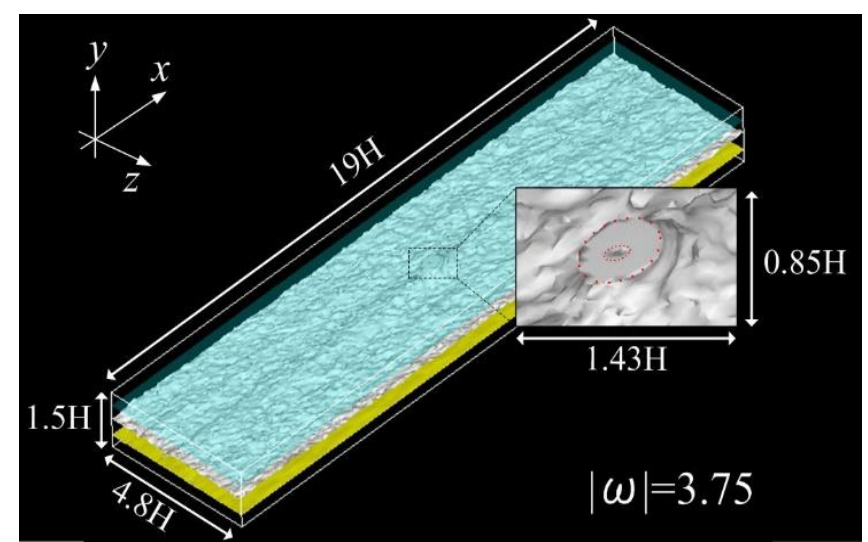

図-14 水面衝突渦の衝突時の三次元構造

の平均的な等值面の高さは $y / H=0.75$ である. 水面下 の等渦度の面から徐々に水面に近づき, 衝突時には 柱状に渦度分布が立ち上がっている．衝突後は，二 脚の渦度の痕跡を残しながら急激に減衰しているこ とがわかる。

水面衝突時の渦度を上方からみたアングルでプ ロットしたのが図-14である。ここで, 渦度絶対值 の等值面を白色, 水面位置を水色, 固体境界面を黄 色でそれぞれ示している。これまでの結果から予測 されるように, 拡大図を見てみると赤い点線で示し たリング状の渦が水面に到達し, 水面によって平面 的につぶれている様子が得られている.

\section{6. おわりに}

本研究では, 粗面開水路流れの水面変動を引き起 こす本質的な要素を抽出するために, LES モデルが 実験の水面変動をある程度再現できていることを 確認した後, 主に LES 解析を用いて水面衝突渦の 特性を調べた. 得られた結果から推定される水面衝 突渦のモデル図を図-15に示す.上流中層付近から 発達したヘアピン渦のヘッドが水面に到達し, リン グ型の渦を発生させ,この組織的な渦構造の衝突が 水面変動を引き起こしている. 粗面乱流場でこのよ うな構造を明らかにした例は皆無であり, 新たな知 見が得られたものと考える。

\section{参考文献}

1) Brocchini, M. and Peregrine, D. H.: The dynamics of strong turbulence at free surfaces part 1: Description, J. Fluid Mech. Vol.449, pp.225-254, 2001.

2) Komori, S., Murakami, Y. and Ueda, H.: The relationship between surface renewal and bursting motions in an open channel flow, J. Fluid Mech., Vol.203, pp.103-123,1989.

3) Smolentsev, S. and R. Miraghaie, R. : Study of a free surface in open channel water flow in the regime from "weak" to "strong" turbulence, Int. J. Multiphase Flow, Vol.31,pp.921-939, 2005.

4) Rashidi, M., Hetsroni, G. and Bannerjee, S.: Waveturbulence interaction in free surface channel flows, Physics Fluids, A4, 2727-2738, 1992.

5) Savelsberg, R. and Van de Water, W.: Experiments on free surface turbulence, J. Fluid Mech., Vol.619, pp.95-125, 2009.

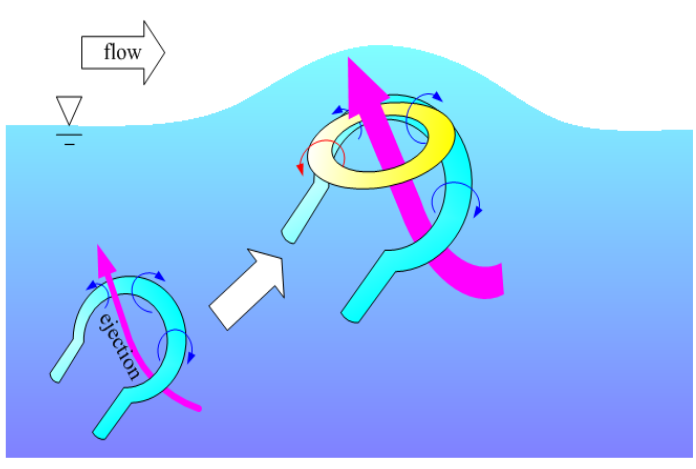

図-15 水面衝突渦のモデル

6) Nakagawa, H. and Nezu, I.: Turbulence in Open Channel Flows (IAHR Monographs), Balkema, 1993.

7) Robinson, S. K.: Coherent motion in the turbulent boundary layer. Annu. Rev. Fluid Mech. 23, pp.601-639, 1991.

8) Jimenez, J.: Turbulent flows over rough walls. Annu. Rev. Fluid Mech. 36, 173-196, 2004.

9) Kirkbride, A. D. and Ferguson, R.: Turbulent flow structure in a gravel-bed river: Markov chain analysis of the fluctuating velocity profile, Earth Surface Processes and Landforms, Vol.20 (8), pp.721-733, 1995.

10) Roy, A. G., T. Buffin-Belanger, T., Lamarre, H. and Kirkbride, A. : Size, shape and dynamics of large scale turbulent flow structures in a gravel bed river, J. Fluid Mech.,Vol.500, pp.1-27, 2004.

11) Fujita, I., Furutani, Y. and Okanishi, T.: Advection features of water surface profile in turbulent open-channel flow with hemisphere roughness elements Vis. Mech. Proc., 1 (4), doi:10.1615/VisMechProc.v1.i3.70, 2011.

12）藤田一郎・小阪純史・萬矢敦啓・本永良樹:遠赤外線 カメラを用いた融雪洪水の昼夜間表面流画像計測, 土 木学会論文集 B1(水工学),Vol.69, No.4, I_703-I_708, 2013.

13）吉村英人・藤田一郎 : 境界埋め込夕法を取入れた LES による開水路栈粗度乱流場の上昇剥離渦の解析, 水工 学論文集, 51 巻, pp.769-774, 2007.

14）吉村英人・藤田一郎: 水面変動を考慮した粗面乱流場 の LES および PIV による解析, 水工学論文集, 52 巻, pp.1015-1020, 2008.

15) 古谷勇樹・藤田一郎 : 速度場と水面変動の同時計測シ ステムを用いた粗面乱流場における水面波形の移流 特性に関する一考察, 水工学論文集, 54 巻, pp.997-1002, 2010.

16）古谷勇樹・藤田一郎：埋め込み境界型 LES を用いた 半球粗面乱流場における水面変動と移流特性に関す る検討,水工学論文集, 55 巻, pp.S1027-S1032, 2011.

17) 岡西健史・藤田一郎・小田崇裕 : 浅水状態で水面変動 のある自然礫床粗面乱流の L E S 解析, 土木学会論文 集 B1(水工学) Vol.69, No.4, I_853-I_858, 2013.

18) 岡西健史・藤田一郎・古谷勇樹: 半球粗度粗面が生成 する水面形のパターン分類とその特性に関する基礎 研究, 土木学会論文集 B1(水工学), Vol.68, No.4, I_1279-I_1284, 2012.

19）禰津家久・中山忠暢 : 自由水面近傍における組織渦の 時空間相関構造に関する研究, 土木学会論文集, 第 586 号/II-42, pp.51-60, 1998.

(2013.9. 30 受付) 